\title{
Wasted Citizenship? Reclaimers and the Privatised Expansion of the Public Sphere
}

\author{
Melanie Samson*
}

\begin{abstract}
A large body of literature explores changes in the public sphere related to the transfer of services and activities performed by the public into the private sector. Less attention has been paid, however, to the privatised expansion of the public sphere. This article explores such a process in Metsimaholo, South Africa, where the municipality sought to bring landfill recycling into the realm of public policy through a public-private partnership. As informal reclaimers had salvaged recyclables at the dump for several decades, this contract amounted to an enclosure of the waste commons which dispossessed them of control over their livelihood and confined them to the informal economy. Countering structuralist accounts of accumulation by dispossession and top-down approaches to governmentality, the article focuses on how reclaimers contested these processes. It argues that before the reclaimers could negotiate with the state, they needed to mount an 'ontological insurrection' to counter their dismissal as mere 'detritus' and demand that the conception of the public sphere be expanded to include them as legitimate actors in the realm of public policy. While this may result in a reconfiguration of the public sphere, it is unclear whether it would challenge the current privatised nature of its expansion.
\end{abstract}

\section{Résumé}

Il existe une littérature abondante sur le transfert des services et activités du domaine public vers le privé. Cependant, la privatisation de l'expansion de l'espace public a été négligée. Cette étude analyse les processus sociaux de contestation par lesquels la Municipalité de Metsimaholo, en Afrique du Sud, a cherché à formaliser la récupération des matériaux recyclables sur la décharge publique de Sasolburg et à

* Department of Political Science, York University and Visiting Researcher, Centre for Urban and Built Environment Studies, University of the Witwatersrand, Johannesburg.E-mail: samson.mel@gmail.com. 
ramener ces activités dans la l'espace de la politique publique à travers un contrat signé avec une compagnie de promotion économique des noirs. Les récupérateurs informels ayant pratiqué la récupération sur cette décharge pendant de nombreuses années, cette tentative par la ville revient donc à interdire l'accès à cette décharge collective privant du coup les récupérateurs du contrôle de leurs moyens de subsistance. L'article défie la perspective structuraliste de l'accumulation par la dépossession et de l'approche paternaliste de la gouvernance. Cette étude analyse la résistance des récupérateurs par rapport à ce processus. Elle défend qu’une "insurrection ontologique » était nécessaire de la part des récupérateurs informels avant de pouvoir négocier avec l'Etat et contrecarrer le rejet qu'ils subissent comme les « détritus », et exiger que l'expansion de l'espace public les prenne en compte en tant qu'acteurs légitimes dans l'arène des politiques publiques. Même si ceci peut résulter à une reconfiguration de l'espace public, le fait que sa nature privatisée puisse être remise en cause n'est toujours pas évident.

\section{Introduction}

In the context of two decades of neoliberalism, a large body of literature emerged, analysing the implications of privatisation for the role and nature of the state. Writing within the same period, Marxist scholars were careful to point out that, contrary to neoliberal rhetoric, rather than withdrawing, the state's role was being transformed to focus more explicitly on facilitating the functioning and internationalisation of the market in the interests of capital accumulation (Panitch 1994). Foucauldian scholars also argued that through processes of neoliberal 'governmentality' the state was extending its reach into the lives of citizens in order to shape and influence how they govern themselves (Burchell 1996; Larner 2000; Rose 1996). The neoliberal state was therefore still very much present in the economy and society, and in many ways its scope was expanding, not contracting. Despite these insights, the literature on privatisation, even when critically engaging with Foucauldian approaches, ${ }^{1}$ still tends to focus on what happens when services previously provided by the state are pushed outside of the public sector and into the private. Less attention has been paid to the privatised expansion of the state, in which new services and activities are being brought into the public domain via public-private partnerships. The importance of interrogating such processes takes on increased significance in the current conjuncture, as states are proactively intervening in the market in new and vigorous ways to help revitalise the post-crisis capitalist economy. 
Waste management provides a particularly useful lens through which to explore these issues, as the moment of neoliberal state restructuring coincided with an increase in environmental awareness and a shift to the promotion of 'sustainable waste management' approaches that focus on 'reduce, re-use, and re-cycling'. Local governments were therefore extending their waste management systems to include recycling at the very time that they were privatising existing waste management services as part of a generalised shift to the 'contracting local state' (Harden 1992).

Within post-apartheid South Africa, local governments face additional pressures to pursue privatised approaches to formally include recycling within the public sphere. At the time of South Africa's democratic transition, the provision of waste management services was inadequate and highly unequal - in 1995 whilst over 90 per cent of Indian and white and 82 per cent of coloured households had their refuse removed by the local authority. This was the case for only 38 per cent of African households. Twenty per cent of African households had no access to any refuse removal whatsoever (Central Statistics 1998:14). South African municipalities therefore face a tremendous challenge in extending service delivery to previously unserviced areas within a context where rocketing fuel and land prices have dramatically increased the costs of waste management, and neoliberal marketisation of municipal government has decreased revenue available and intensified pressures for services to be financially self-sufficient (Barchiesi 2007; Harden 1992; McDonald 2002; Samson 2007). Since the adoption of the National Waste Management Strategy in 1999 (Department of Environmental Affairs and Tourism and Department of Water Affairs 1999) the South African government has promoted a 'cradle-to-grave' approach to waste management which foregrounds recycling as a means to reduce the amount of waste going to landfills. As recycling has long been conducted by informal reclaimers and buyers who function independently from the state, the incorporation of recycling into municipal waste management systems represents an expansion of the public sphere. Most municipalities are, however, preferring to implement this extension through public-private partnerships in which companies are granted exclusive right to reclaim materials on municipal landfill sites.

As the ILO points out, although the waste on municipal landfills is technically the property of the relevant local municipality, until waste systems are formalised waste is better understood as a common property resource. Granting a private company exclusive right to reclaim material from a dump therefore requires a municipality to enclose the garbage at the landfill and transform it into private property, the rights to which can then be sold or rented to the company (International Labour Organisation 2004:22). This approach to incorporating recycling into the public sphere can, therefore, be 
understood as part of the broader process of 'accumulation by dispossession' (Harvey 2005) in which neoliberal governments are creating new spheres of accumulation for capital. Importantly, by transforming garbage into a commodity which private companies will pay to access, this process also creates new sources of revenue for cash-strapped councils whilst simultaneously decreasing the amount of space (and financing) needed for landfills.

As noted by Hart (2006) and de Angelis (2006), rather than being the simple outcome of structural necessities, accumulation by dispossession must be seen as a contested social process. When exploring the enclosure of the waste commons, it is therefore critical to interrogate how this process is shaped by, relates to and reconfigures social relations within the sector. This paper contributes to this agenda by exploring the paradoxical position of informal reclaimers in processes to enclose garbage and bring recycling processes into the formal, privatised public sphere. It is based on a case study of the contested history of public-private partnerships for the reclamation of recyclable materials from the Sasolburg landfill site in the Metsimaholo municipality in South Africa's Free State province².

The paper traces the processes through which reclaimers ${ }^{3}$ established their informal rights to the garbage on the Sasolburg landfill, staved off the enclosure of the landfill for an extended period of time and managed to negotiate the terms of their integration into the formal economy. Based on analysis of the activities and self-definitions of reclaimers, the paper argues that they could be seen as prototypical 'neoliberal citizens' proactively mobilising to promote their self-interest and sustain their own livelihoods (Rose 1996:158). However, the national state failed to grant them legibility within the sphere of legislation and public policy, and as they were viewed as the 'detritus' (Chari 2005) of modern society, the local state actively discriminated against them in the practices of governance. As a result, they were not considered to be legitimate participants in public policy processes related to the formalisation of recycling on the landfill. The extension of the public sphere via the granting of a contract to a private company to recycle materials on the Sasolburg landfill therefore exacerbated the marginalised position of the reclaimers. Rather than building a bridge out of the second and into the first economy, as is the stated objective of South African policy (ANC NGC 2005), this process threatened to contain the reclaimers within the informal economy and preclude their active participation in public processes. Although the reclaimers had been unable to significantly shift this terrain, contrary to the top-down assumptions often made in the governmentality literature, they were not passively accepting the ways in which they were constructed and treated by the state. They rejected the 
label of 'scavengers' and were actively organising to assert their right to participate in and shape the nature of the extension of the formal waste management system. As such, they were mounting what Judith Butler refers to as an 'insurrection at the level of ontology' by seeking to expand the notion of who is a legitimate actor within the public sphere (Butler 2004:33). However, whether this will challenge the current neoliberal nature of expansion of the public sphere remains unclear.

In order to substantiate this argument, the paper begins by providing an overview of the contested processes to privatise and formalise recycling on the Sasolburg landfill. The remainder of the paper then seeks to theoretically unpack that history. The second section draws on Chari's notion of detritus (Chari 2005) to reflect on why, despite the fact that reclaimers exhibited many of the characteristics of neoliberal citizens, they were rendered invisible within waste management policy and legislation and actively discriminated against in practice. The third section examines the attempts by reclaimers to reconfigure the public sphere and their place within it. The final section summarises the key arguments made in the paper and reflects on the broader implications of these struggles for the neoliberal nature of expansion of the public sphere to include recycling.

\section{Contested Processes to Formalise Recycling at the Sasolburg Landfill}

The Sasolburg Landfill is located 3.6km from the town of Sasolburg in the Metsimaholo Municipality in South Africa's Free State Province. Metsimaholo is comprised of Sasolburg, Zamdela, Viljoensdrif, Coalbrook, Deneysville and Oranjeville. The town of Sasolburg was founded in the 1950s to provide housing for skilled white workers employed by the petrochemical company Sasol, while the township of Zamdela provided single sex accommodation for black male Sasol employees. With the decline of the apartheid era's influx control, Zamdela became the home to many families. In 2008, more than 50 per cent of Metsimaholo's population of 173,448 resided there (Kwezi V3 Engineers 2008:18). In 2006, Metsimaholo's official unemployment rate was 33.4 per cent, which was slightly below the national average (Metsimaholo Municipality 2008:36). In 2008, agriculture was the largest local employer, accounting for 30.7 per cent of employment, and only 13.1 per cent of employment was in the manufacturing sector (Metsimaholo Municipality 2008:47). However, as will be elaborated below, Sasol continued to dominate the political landscape and have tremendous influence over the local council. 
The Sasolburg landfill was established in 1951. It is the main landfill servicing the Metsimaholo Municipality, with two smaller landfills located in Deneysville and Oranjeville. The Sasolburg landfill receives domestic waste from Zamdela and Sasolburg, as well as industrial waste from the large number of factories in the surrounding area. It was estimated that in 2008 the landfill received 90 tonnes of waste per day. ${ }^{4}$

The temporary permit received by the landfill in June 1990 expired and the site was not permitted at the time of the research. In reality, it was more of a dump than a landfill. It was not lined, there was no weighbridge and a fence was only been erected in 2008. Reclaimers reported that hazardous waste was frequently dumped at the site. Municipal presence at the dump was minimal, with only one municipal employee toiling alone with a bulldozer to cover the rubbish and one permanent employee keeping records of the vehicles that entered the site.

By contrast, there was a thriving community of reclaimers at the dump. Reclaimers had been salvaging recyclable material from the dump since at least the 1980s. While a small number of those interviewed had worked on the dump for more than fifteen years, the majority had taken up the work of reclaiming within the previous eight years. As in other places across South Africa and around the globe, as unemployment rose due to neoliberal restructuring, reclaiming became an increasingly important livelihood strategy for those excluded from the realm of wage labour (see for example, Medina 2007; Webster et al. 2007; Millar 2006). Contrary to the common assumption that reclaimers have low levels of education, many of the younger men on site had high proficiency in English and had completed some secondary education. Most of the older men and women interviewed had previously held other employment but, since being retrenched or dismissed, had been unable to find other paid jobs. One of the young, male reclaimers explained that they had resorted to reclaiming as, 'it is just that we see there are no jobs and we must make our own'.

The reclaimers were primarily seSotho speaking South Africans who lived in the surrounding townships and informal settlements. Some previously lived on the dump itself. However, after years of failed attempts, the municipality succeeded in evicting them early in 2008. The reclaimers had divided themselves into two groups, based on the type of materials that they collected. Due to the social division of labour, this separation was also broadly based on gender and age. Collection of scrap metal was the exclusive domain of young men who formed a group called Ditamating ${ }^{5}$ Scrap Metal Project. The women and older men who worked on the site collected paper, plastics and glass. They were organised into the Ikageng ${ }^{6}$ Landfill Committee. Both organisations were registered as closed corporations. 
Ditamating and Ikageng had carved up the space of the landfill and demarcated separate working areas where they sorted and stored their materials. Although the reclaimers from the two groups passed through each others' spaces and sometimes rested or laboured near one another, there was a clear spatial division between the two groups. This was a stark, physical manifestation of the long-standing tension between them. Although members of Ditamating said they were willing to work with Ikageng, the older men and women alleged that the young men were ill-disciplined and disrespectful and that they poached their materials. Ikageng members insisted that they could not and would not work collaboratively with Ditamating.

Despite these divisions between the two groups, the interior of the dump was clearly the domain of the reclaimers. They had designed the physical layout of the dump around the working face, and aside from regular battles with the bulldozer driver over the pace at which he covered the garbage, they had almost complete command over the labour processes through which they retrieved and sorted materials. However, as will be elaborated below, the violent enforcement of a contract that granted a private company called Phutang sole property rights to the dump's garbage dramatically curtailed the ability of the reclaimers to control the remaining processes through which reclaimed materials were transformed back into commodities.

This contract was not the first time that the municipality had tried to formally incorporate recycling on the dump into the waste management system via a public-private partnership. This type of privatised expansion of the public sphere was first attempted in Metsimaholo more than twenty years ago and there had been several previous contracts with other companies. Within each of these contracts, the actual work of reclaiming recyclable materials was performed by the informal reclaimers, who technically were allowed to remain on site only if they sold their materials to the company holding the contract. However, the terms of the contracts were never fully implemented. As the municipality failed to fence the site and provide adequate security, the companies could not establish their claim to the physical space of the dump. Although by all accounts the paper, plastic and cardboard reclaimers mainly sold to the contract holders, they could also arrange transportation to sell their goods to buyers offering higher prices in other locations, or could sell to other buyers who made it onto the dump itself. According to the scrap reclaimers, the penultimate company did not deal in scrap, and so they developed an ongoing relationship with a different buyer. The companies holding the contract refused to pay rent as their monopsony power was not realised and no recycling infrastructure was developed at the dump. In this period, inclusion of recycling in the public sphere amounted to nothing more than placing tremendous pressure on the reclaimers to sell to one particular buyer. 
In approximately 2004, presumably due to insufficient profits, the company holding the contract abandoned its operations at the dump. This vacuum created space for the reclaimers to assert control over the sale of their products and negotiate the terms on which they related to the formal recycling industry. The reclaimers dealing with paper, cardboard and plastic arranged with DJ Afvalpapie, one of the largest purchasers of these materials in the region, to provide them with skips and collect their materials on a regular basis. The scrap reclaimers realised that by bargaining with different buyers, they could obtain higher prices. Rather than selling to only one buyer, they developed relationships with three different purchasers. They also began to work and sell their goods collectively. As they were selling in bulk, they managed to obtain higher prices and significantly increase their income.

The reclaimers were now unofficially in charge of the recycling processes at the dump. They aspired to formalise their place within the waste management system and have their role recognised in the public sphere. Both groups of reclaimers asserted that during this period, they were told by the Assistant Manager for Health and Cleansing Services that if they wanted to receive the contract, then they would have to form a collective, as the contract could not be given to individuals. According the reclaimers, this was the catalyst for the formation the Ditamating Scrap Metal Project and the Ikageng Landfill Committee. The municipal officials denied that during this period, the reclaimers were organised or indicated an interest in obtaining the contract for themselves. What is, however, undisputed is that the reclaimers were neither informed nor consulted when a new contract was awarded without having been advertised or put out for public tender. The informal reclaimers who performed the labour of salvaging materials from the dump and who had been effectively running the recycling processes for an extended period of time, were rendered invisible and not seen as stakeholders in this public policy process.

By contrast, significant assistance and resources were provided to two black, male professionals from Zamdela to help them to build their newly formed Phutang recycling company and secure the contract. By their own admission, neither of the aspirant entrepreneurs had any real experience with recycling. ${ }^{7}$ However, they saw that there was an opportunity to make money from recycling. They approached Council to obtain the right to recycle at the landfill and requested financial assistance from Sasol to help them start the business. According to a representative of Sasol, once the entrepreneurs had received in principle agreement from Council, Sasol assisted them in securing the necessary equipment ${ }^{8}$. Sasol could not provide funding to entrepreneurs. Under the rubric of a joint business-council initiative called 
Rejuvenation (of which Sasol was the main donor), Sasol therefore channelled resources via the Vaal Regional Community Trust (of which Sasol was also the main donor) for the donation of a container and pressing machine to Phutang as well as for the provision of an interest-free loan for the purchase of a small truck. The manager of corporate affairs at Sasol, who was the deputy chairperson of the business chamber, also arranged for a wellestablished white businessman to act as an advisor and mentor to Phutang. With these human and physical resources in place, the Sasol representative reported that Phutang was able to seal the deal with Council. According to the Assistant Manager Health and Cleansing Services for Council, the sequence of events was somewhat different, with Phutang first receiving the support and then Rejuvenation requesting that Council give them the contract. Regardless of this disagreement about sequencing, four things remain clear. First, Phutang had no relevant expertise in recycling or business more generally and prior to receiving support from Sasol/Rejuvenation had no access to capital required to run a business. Second, support from Sasol/Rejuvenation played a critical role in ensuring that Phutang received the contract. Third, the contract was awarded without being publicised or put out to tender. Fourth, the reclaimers were completely excluded from these processes and discussions. Support for 'black economic empowerment' was cited by a council official as the reason why the contract was given to Phutang without going to tender, something which the reclaimers, who are also black, found ironic. As the leader of Ditamating argued, 'if it is about empowering people, then they must start with people from the site'. However, this was not an option considered by Council, Sasol or Phutang.

It was universally agreed, even by Phutang itself, that Phutang failed to manage the recycling of materials from the dump. Both directors of Phutang remained in their full-time jobs and, according to a representative from Sasol, attempted to 'run the business by cell phone and remote control'. They had no hands-on experience with recycling and had not even undergone training to help them identify the different types of metal being sold by the scrap reclaimers. For an extended period of time, Phutang had insufficient cash flow, was unable to purchase the materials from the reclaimers on a regular basis, and was on the verge of bankruptcy. When Phutang did purchase materials from the reclaimers, it did so at a significantly lower price than that which they had previously received. This is not surprising, as Phutang sold to the same buyers that the reclaimers had previously dealt with directly but was now taking a cut for itself. Although it is possible that Phutang managed to negotiate a higher price with paper, plastic and cardboard companies by selling in bulk, it must be remembered that the scrap reclaimers had already 
achieved these economies of scale by selling collectively. The decrease in income reported by the reclaimers was in line with the findings from an international study by the ILO that privatisation usually resulted in lower income for reclaimers as the private companies with monopsonies extract rent from the reclaimers (International Labour Organisation 2004:22).

For several months, Phutang was completely absent from the site and the reclaimers continued to manage all processes related to salvaging on the dump. By the beginning of 2008, both Ikageng and Ditamating had registered as closed corporations in order to assist their bids to take over the contract. According to the reclaimers, both groups once again approached the municipality to have their role formalised, and they offered to pay the municipality rent for their access to the dump. However, they were informed that it was impossible to cancel the contract. Senior waste management officials justified this by arguing that Council had not upheld its part of the contract as it had failed to fence the landfill and provide the security required to secure Phutang's monopsony.

Ditamating members reported that they approached Phutang and suggested that, as Phutang had no knowledge or experience in dealing with scrap, they should give them a subcontract. However, instead of partnering with reclaimers who had intimate knowledge of scrap metal and had demonstrated their ability to negotiate with and deliver to large purchasers of these materials, in May 2008 Phutang merged with Remade, a large white-owned recycling company with branches across the Southern African region. A primary attraction of merging with Remade was that it had financial capital to help pay off debts and run the business, something which the reclaimers obviously could not offer on their own. However, it is important to note that despite its size, Remade's manager on-site stated that the company had no knowledge or experience in dealing with scrap.

The merger with Remade caused some unease in Council and Sasol as it undermined the objective of black economic empowerment. However, both Council and Sasol were determined to ensure that the contract ran smoothly. Council was aware that recycling from the dump should be able to generate significant revenue. It was keen to finally start benefiting financially from the deal so that it could obtain additional resources for the chronically underfunded waste management department. For its part, Sasol had an interest, clearly articulated by its representative, in ensuring that the loan would be repaid and that order would be brought to the dump, which bordered on land owned by the company. 
As Council did not see the reclaimers as a legitimate constituency worthy of consultation, it did not consider negotiating with them to get them to sell to the contract holder. By Council's own account, the only purpose of the few meetings held with the reclaimers was to inform them that they must behave appropriately on the dump and that they must sell their materials to Phutang. No attempts were made to persuade them to agree to work with Phutang by addressing their concerns that they were being forced to sell their goods at a lower price and that their incomes were being decreased due to the imposition of Phutang as the sole buyer.

Instead, Council and Sasol turned to a security solution. Even before the merger, they decided that it would be necessary to physically enclose the dump in order to force the reclaimers to sell to Phutang and ensure that the company benefited from its monopsony. The fence was also crucial if the Council was going to secure the cooperation of the police in this process. In the past, Council had called the police on numerous occasions to physically remove the reclaimers. However, as there was no fence and minimal security, the reclaimers would simply wait a few days and then re-enter the site. As a result, in May 2007, the police had informed Council that they were no longer willing to forcibly remove the reclaimers unless a fence was in place and they were issued with arrest warrants for the reclaimers. Due to the perceived importance of the fence, Sasol agreed to finance 60 per cent of the costs of constructing a fence completely encircling the landfill.

By the time that Phutang merged with Remade and the company was ready to assert its authority, the fence was almost completed. The council and the company therefore took decisive action. In May 2008, RemadePhutang insisted that all reclaimers on the site sign a contract agreeing to only sell their materials to Remade-Phutang, otherwise they would be evicted from the site. The reclaimers refused and embarked on industrial action in which for a period of several weeks they refused to sell to Remade-Phutang. A stand-off ensued as Remade-Phutang had deployed additional security to the gate, thus preventing the reclaimers from removing their materials from the site and selling to other buyers. Neither the reclaimers nor RemadePhutang could generate any income. On May 22, 2008 the reclaimers were summonsed by Council to attend a meeting at 8am on May 23, 2008, nonattendance of which, they were informed, would 'leave the council with no option but to use its legal process to remove you out of the dumping site'. ${ }^{9}$ The reclaimers attended the meeting and tried to raise their grievances. They once again refused to sign the contracts. The police were subsequently sent in with dogs and pepper gas to remove them. As noted above, this was not the first time that the police had been sent in. However, now that the dump 
was physically enclosed, once the reclaimers were evicted, they were aware that it would be much more difficult to re-enter the site. In addition, they had not earned any income in the preceding few weeks due to the stand-off with Remade-Phutang, and the police did not let them take their possessions with them. The combination of the police and the fence broke the reclaimers' ability to continue with their resistance. One reclaimer eloquently summarised the outcome of what she perceived as a hard-fought battle stating, '[w]e were chased away by the police on a Friday. We came back on Monday to surrender and sign the contract'.

After that, an uneasy truce was reached on the site. Almost all of the reclaimers signed the contracts. As it became impossible to sell to other buyers, Remade-Phutang allowed those who had not signed to continue working on the site. Representatives of Council and Remade-Phutang all reported that the 'problems with the reclaimers' had been resolved and the contract was moving forward. However, the reclaimers reported a litany of problems with Remade-Phutang. They continued to receive less money than in the past for their materials and Remade-Phutang was reneging on the clauses in the contract that required it to provide the reclaimers with uniforms, safety equipment and sufficient access to water and toilets. In addition, Remade did not have experience in dealing with scrap metals and the reclaimers claimed that the prices paid did not differentiate between all of the different types and grades of metals that they sold, thus leading to lower overall payment.

The imposition of the Remade-Phutang's monopsony meant that the reclaimers were no longer free to negotiate the terms on which they related to and potentially entered into the formal economy. Paradoxically for a programme which was intended to bring recycling into the formal, public sphere the contract with Remade-Phutang forced the reclaimers to recede back into the sphere of the informal. According to the local manager, Remade-Phutang had no plans to empower the reclaimers, other than to teach them how to sort materials, something at which they were arguably already highly skilled.

Significantly, for the scrap reclaimers, Remade-Phutang required them to register and sell their materials individually. The company therefore succeeded in undermining the previously collective approach of the members of the Ditamating Scrap Metal Project. Although they did so less frequently, both Ditamating and Ikageng continued to meet and tried to strategise their next moves. They were wounded and bitter. They recounted that they had believed the ANC campaign slogan and expected a 'better life for all' with the advent of democracy. However, they reported that they had lost faith in council and were tired of knocking on endless doors and not being taken 
seriously by the Council. When asked what had changed since apartheid days, one woman reclaimer responded that, 'there is no change as the police still chase us away'. Members of Ditamating observed that the imposition of Remade-Phutang not only compromised their rights as citizens to participate in the policy process, but also undermined their ability to fulfil their obligations as citizens, noting that, 'we are citizens of this city. We are expected to pay for services. We used to pay for services, now it is difficult'.

Indeed, this history of the contested processes through which recycling was being formalised in Metsimaholo raises a number of pertinent issues related to citizenship and the construction of the public sphere. The remaining sections of this paper locate and unpack this history theoretically and explore how the process in Metsimaholo was predicated on particular understandings of who is a legitimate actor within the public sphere. This analysis begins in the following section by theorising why reclaimers were so marginalised within the expansion of the Metsimaholo waste management system.

\section{Neoliberal Citizens or Detritus?}

In seeking to theorise the role of the reclaimers, it is useful to turn to the burgeoning literature that draws on Foucault's concept of governmentality to explore the form and nature of citizenship in the context of neoliberalism. Foucault uses the concept of governmentality to understand the 'how' of governing (Gordon 1991:7) by studying the political rationalities and technologies of government (Rose 1996:42). Central to governmentality within liberalism and neoliberalism is the understanding that individuals have agency. Individuals are therefore seen as, 'on the one hand, the object and target of governmental action and, on the other hand, as in some sense the necessary (voluntary) partner or accomplice of government' (Burchell 1996:23). Governmentality is therefore understood as the 'conduct of conduct', or, 'as a way of acting to affect the way individuals conduct themselves' (Burchell 1996:20). A key component of neoliberal governmentality is the creation of neoliberal subjects who see their lives as an enterprise and take responsibility for achieving their own individual goals, which are shaped in line with the broader neoliberal project (Gordon 1997). Much of the governmentality literature therefore focuses on the ways in which government policy constructs particular categories of the population to create neoliberal citizens who believe in self-reliance and do not expect the state to provide them with what were previously seen as the rights of citizenship.

As should be evident from the previous section, the reclaimers were perhaps the prototypical neoliberal citizens. Having accepted that neither the state nor industry would provide them with employment, they took the initiative to create their own income. Through their labour, they performed 
something akin to alchemy as they took what others deemed waste and transformed it back into a marketable commodity. When left free from interference from the state, the police and monopsonistic private companies, they succeeded in working collectively, marketing their own goods and transforming and improving the terms on which they were articulated into the formal economy. Both the Ikageng Landfill Committee and the Ditamating Scrap Metal Project had registered as closed corporations and had ambitions to formalise their activities. Both believed that if they won the contract they would be able to formalise their work and register for workman's compensation and unemployment insurance. They also stated that if they could be provided with assistance to purchase pressing machines and transport, they would be able to expand their businesses and create employment for other people. Ditamating reported that it proposed to waste management officials to start a programme in the community to get households to separate waste at source, something which it would pursue if it had the opportunity. If granted the contract, it also planned to hire a manager to help it run its operations professionally. The women in Ikageng dreamed that, with formalisation, they would be able to create a fund to provide support to children in the community who could not afford school fees so that they would stop trying to come to the dump to earn money. As noted above, both groups were willing to pay the municipality for the right to reclaim materials from the site. Given the opportunity to pursue their vision, the reclaimers would have provided a rare, successful example of the government's illusive goal of helping people to move themselves out of the 'second' into the 'first' economy ${ }^{10}$ (ANC NGC 2005). But instead, Council single-mindedly pursued an approach which decreased their income and consigned them to remain as individual, informal reclaimers with no prospects to empower themselves, move into formal employment or grow their collective businesses.

How then does one explain the complete marginalisation of the reclaimers within processes to formalise recycling in Metsimaholo and include it in the public sphere? Part of the answer lies in their lack of legibility within national waste management policy and legislation. Reclaimers are not mentioned in any South African legislation. In her insightful review of the current policy context, Benjamin (2007) notes that although the National Environmental Management Act 107 of 1998 endorses recycling as a key element of waste minimisation strategies, it does not recognise the role of what she refers to as 'scavengers' in existing recycling processes. As Benjamin observes, '[t]he lack of recognition for scavenging from the highest environmental legislation of the country presents significant tensions with other policy documents....These policy documents mention scavenging and ways to handle 
or regulate this work but without placing a legally binding obligation on those who are responsible for waste management, including the Department of Environmental Affairs and Tourism' (Benjamin 2007:39). Moreover, when it comes to policy implementation, although the Minimum Requirements for Disposal of Waste by Landfill allow individual landfill site managers to decide whether to allow salvaging on their sites, managers who do so must indemnify the department from any responsibility, creating a strong disincentive for the legitimisation of reclaimers (Benjamin 2007:7-9).

The Waste Bill under consideration in 2008 would not dramatically alter this situation. The Bill seeks to develop sustainable waste management systems across the country and promotes the reduction, re-use and recycling of waste. It recognises that waste can be a valuable economic resource and that, 'the impact of improper waste management practices are [sic] often disproportionately borne by the poor' (Republic of South Africa 2007a). It is therefore ironic that, initially, the Bill contained no reference to the legions of informal reclaimers who support themselves by recycling waste material and did not include any mechanisms to improve their status within waste management systems. After lobbying by civil society organisations, the proposed amendments to the bill basically leave the status quo from the Minimum Requirements unaltered, and simply stipulate in Section 51(1) that, '[a] waste management license must stipulate (i) if applicable, the conditions in terms of which salvaging of waste may be undertaken' (Republic of South Africa 2007b). The Bill does not, however, provide any guidance regarding when salvaging should be permitted or how this should be done.

While reclaimers are rendered virtually invisible in the sphere of legislation, key waste management documents that do refer to them make it clear that it is government's intention to actually eliminate reclaimers themselves in the long term (Department of Environmental Affairs and Tourism and Department of Water Affairs 1999). Government is correct in identifying that salvaging at landfill sites has problematic health and safety implications. However, complete loss of income is an even graver threat to the health of the reclaimers and their families. Advocating the elimination of reclaiming without a clear process to ensure that reclaimers are involved in future recycling initiatives is further indication of government's failure to recognise reclaimers as legitimate stakeholders within the public sphere. This official silence at the level of national policy and legislation creates the space for local councils such as Metsimaholo to disregard and marginalise reclaimers and treat them with contempt in local processes to formalise recycling. 
But what is the basis of this contempt? Why were Council and business representatives unable to see the reclaimers as good neoliberal citizens with the right to participate in the formalisation of recycling initiatives? Here, it is useful to turn to the work of Sharad Chari and his notion of 'detritus'. In his research on the Durban community of Wentworth, Chari (2005) develops the concept of 'detritus' to capture how capital accumulation and colonialism create surplus populations compelled to find ways to reproduce themselves outside of the wage labour relation and as well how these marginalised populations are often forced to contend with the toxic industrial detritus generated by capitalist production. This concept can be productively drawn on to theorise the ways in which reclaimers are framed and understood. In a context where neoliberal restructuring has made formal employment an impossibility, reclaimers turned to salvaging recyclable material from society's physical detritus as a means of survival. Research from a range of contexts reveals that reclaimers are frequently reviled, stigmatised, ostracised, and treated as expendable ${ }^{11}$ as they become associated with the detritus that they rummage through (Benjamin 2007; Beall 1997; Chikarmane and Narayan 2005; Huysman 1994; International Labour Organisation 2004; Medina undated; Millar 2006; Rogers 2005 Tejani April 2003). The case of Metsimaholo is no different. All council representatives interviewed used the term 'scavenger' to refer to the reclaimers (although some changed their language when I used different terminology). Reclaimers stated that they were always referred to in this way by Council and that they resented this title as a 'scavenger is something that lives with dirt'. Given that they work with and are defined by their relationship to waste, in the case of reclaimers, the term 'detritus' is therefore more than metaphorical.

In seeking to explain why Council did not engage with them, one of the scrap reclaimers perfectly captured Chari's notion, stating that, 'these people there see us here [at the dump]. They just take us for granted. Even if you have a serious problem they don't listen. They say you are just people from the dumpsite. You are just scrap'. Council officials did not recognise the reclaimers as a legitimate constituency in the waste management system, and when asked whether there should be consultative processes and empowerment programmes put in place for them to actively participate, the Manager, Health and Cleansing Services responded that, 'they are residents of the municipality. So they can't be given any extra rights. It is up to them to make sure they take advantage of the opportunities available to residents' ${ }^{12}$

Members of Ikageng believed that an official who told them they could get the contract if they formed a group, 'was just saying that. He never thought the elders could register a business'. Indeed, forming the closed 
corporations made little difference. At first, both Council officials and the director from Phutang refused to acknowledge that the reclaimers had formed closed corporations. When they did admit to this, they did not grant it any relevance, and the Manager, Health and Cleansing referred to them as, 'socalled ccs'. The assistant Manager, Health and Cleansing Services made clear his disdain for the reclaimers and their companies, stating: 'we wouldn't give the contract to those companies as they were working against the municipality and Phutang. They were threatening us and throwing stones. They want to make it uncontrollable as they think then they will get the contract'. Whilst it is true that the reclaimers had engaged in disruptive and at times aggressive behaviour, once they were denied any opportunity to participate in formal processes, they had little option but to resort to direct action. It is therefore quite ironic that management then seemed to consider such behaviour a natural attribute of reclaimers.

In addition to being cast as unruly, the reclaimers were depicted as uneducated and unskilled, characteristics which were deemed to render them ineligible to win the contract. The leader of Ditamating described the surprise of the directors of Phutang when in their first formal meeting he challenged them in fluent and articulate English. He explained that, 'they didn't think there were educated people here. But then they realised I was educated when they heard me speak. They always use English in their meetings. We did query them about that. They say it is an official language'. He was convinced that Phutang purposefully used English in order to reinforce power differentials with the reclaimers, many of whom were not as proficient in this language. He stated that whilst the directors of Phutang began to treat him with more respect due to his language skills, they continued to be dismissive of the other reclaimers, whom they assumed to be uneducated.

Perhaps most tellingly, the Council officials and Sasol representative were all clear that the reclaimers did not have the skills or capacity to run recycling operations on the dump. In addition to their lack of business skills, it was also noted that they did not have any machines or equipment required to run the business. The reclaimers reported that this was put to them bluntly by one councillor who said, 'you are talking a deal of millions of rands, but you don't even have a car. What do you expect us to do?' The tremendous irony in this situation is that the reclaimers had a proven track record of managing themselves and negotiating the sale of their goods with formal enterprises. Their plans for the dump were based on this experience. As the leader of Ditamating explained, 'we know what happened before so we worked on the base of that to develop the proposal and business plan'. Aware of their limitations, they attended a workshop run by an NGO to help them develop 
a business plan, and also intended to hire a manager to help them run their operations. By contrast, the Directors of Phutang had no background in recycling, no experience in business, and no access to capital or equipment before they received support from Sasol/Rejuvenation. Even with the assistance of the advisor provided by Sasol/Rejuvenation, they had proven themselves to be utterly incapable of running the business. However, they were professionals who were well respected in the community, and key players in Sasol/Rejuvenation and Council obviously could not see past the detritus when they look at reclaimers.

\section{Reconfiguring the Public Sphere?}

Given that the reclaimers were not seen as legitimate actors within the public sphere, successful mobilisation necessitated more than simply demanding that they be allowed to participate in public policy processes. It would require a transformation of the very conceptualisation of the public sphere itself. As Judith Butler argues, '[t]he public sphere is constituted in part by what can appear, and the regulation of the sphere of appearance is one way to establish what will count as reality, and what will not' (Butler 2004:xx$\mathrm{xxi})$. She further argues that, ' $[\mathrm{t}] \mathrm{o}$ decide what views will count as reasonable within public domain...is to decide what will and will not count as the public sphere of debate' (Butler 2004:xx). What Butler is arguing is that the construction of the public sphere is predicated on defining certain people as legitimate members of the public sphere, and certain ideas as permissible within this realm. Other views and other people are, per definition, defined as lying beyond its bounds. As detritus, the reclaimers did not feature within the council's conception of the public. Mobilisation by reclaimers would therefore require, 'an insurrection at the level of ontology' (Butler 2004:33) to both redefine how they are seen and to establish that they be accepted as valid members of the public sphere. The possibility of such insurrection within Butler's framework is crucially important. It highlights the dynamic and contested nature of the production of the public sphere and legitimate agents, something which numerous scholars (see for example Goldsworthy 2006; Hart 2008; O’Malley, Weir, and Shearing 1997; Rutherford 2007; Watts 2003; Weszkalnys 2007) have pointed out is missing in the Foucauldian governmentality literature, which sees governing as already accomplished, and the construction of legible subjects as a one way, top-down process.

Ontological insurrection involves engagement at multiple levels, starting with the reclaimers themselves. Building on Chari's work Massimo de Angelis emphasises how detritus is productive of, and becomes inscribed within people's bodies and subjectivities (de Angelis 2006:67). A first stage of struggle therefore lies in those deemed to be detritus rejecting this construction of 
themselves and claiming the right to define their own identity. The Ditamating members were particularly clear and articulate on this point. As noted above they rejected being called scavengers, due to the pejorative association of scavengers with dirt. When asked what they would like from the municipality, the first response of the leader of Ditamating was, 'if they can accept our position and that we are here as workers. If they can accept that there is life here, we can make life out of this place'.

A second level of insurrection relates to the development of collective identities and the insistence that these identities be recognised by the Council. When asked what forming the company meant to them, a member of the Ikageng Landfill Committee said, 'we were very, very happy when we registered the company. Were very proud and thought it would help us to get the contract'. The tremendous joy on the faces of the women as they discussed the establishment of the closed corporation affirmed that their pride was about much more than simply setting up a company. It was about their ability to disprove the officials who believed they weren't capable of achieving such a goal, and the receipt of formal recognition of their existence, even if at this stage it was only from the registrar of companies and not from Council.

Nevertheless, despite collective organisation, the formation of legal corporate entities, industrial action and repeated demands to be heard, Council representatives continued to refer to the reclaimers as scavengers, to disregard their organisations, and refused any substantive engagement with them on issues of profound importance to their livelihood. The insurrection to reconfigure the public sphere therefore continued unabated. A key challenge for the reclaimers in waging this insurrection would be to find ways to grapple with and address the power hierarchies and divisions based on age and gender that currently divide them.

\section{Conclusion: Reconstituting the Public Sphere?}

This paper has explored the Metsimaholo muncipality's attempts to formalise recycling on the Sasolburg landfill. By enclosing the waste commons and granting a private company the sole right to extract recyclable materials from the dump, the Council literally expanded the public sphere, albeit via a public-private partnership. This privatised extension of the public sphere had profoundly negative effects for the informal reclaimers who performed the actual labour of salvaging materials from the dump. Prior to the enforcement of this enclosure the reclaimers had succeeded in managing operations on the dump and negotiating the sale of their goods directly to some of the largest recycling companies in the region, thus redefining the terms of their relationship with the formal economy. However, the implementation of the contract compelled them to recede from their active negotiations and en- 
gagements with the formal economy and threatened to ghettoise them within the space of the landfill and the sphere of the informal economy. In seeking to understand why the Council marginalised and ignored the reclaimers, the paper has argued that although the reclaimers were the ideal neoliberal citizens, as the local state viewed them as the detritus of modern society, it was unable to see their positive attributes or accept them as legitimate actors in the public sphere.

This does not, however, mean that the reclaimers were doomed to forever occupy this space. As noted above, the governmentality literature has been widely and correctly critiqued for conceptualising policy as a top-down process and seeing contestation as only responsive to and not constitutive of processes of governing (see for example Goldsworthy 2006; Hart 2008; O'Malley, Weir, and Shearing 1997; Rutherford 2007; Watts 2003; Weszkalnys 2007). Although the reclaimers had not yet succeeded in establishing their legitimacy as a population category within Metsimaholo's waste management policy, they were actively challenging their invisibility by forming closed corporations, engaging in industrial action, and continuing to demand meetings with Council and the Remade-Phutang. Such struggles have played an important role in transforming waste management policies and the role of reclaimers within them in other contexts. For example, in Brazil, mobilisation by reclaimers has resulted in several categories of 'collector of recyclable materials' being officially recognised as occupational categories, and reclaimers are valued as a key constituency within the sphere of waste management (Dias 2006, 2007).

If the reclaimers do eventually succeed in either winning the contract for themselves, or at least improving the terms of the existing contract, they will have transformed their literal position within the waste management system and the public sphere. But at a more abstract level, they will also have succeeded in reconfiguring the ontology of the public sphere itself. Whilst this would clearly amount to rendering the public sphere more inclusive, it is questionable whether it would fundamentally transform the current neoliberal nature of the extension of the public sphere. Both the Ikageng Landfill Committee and the Ditamating Recycling Project wanted to operate as private companies with public-private partnership contracts with the Council. They had no desire or intention to bring their activities into the state itself and they had a vested interest in maximising both their profits and their autonomy. Whether they could develop a way of working that presents a substantive alternative to more established private companies, and indeed whether they even aspire to this goal, remains to be explored. 


\section{Notes}

1. See, for example, Greg Ruiter's insightful analysis of pre-paid metres in South Africa (Ruiters 2007). Building on insights from the governmentality literature, Ruiters argues that pre-paid metres were intended to transform service recipients into 'self-disciplining' subjects and obscure social austerity. However, overcoming weaknesses in the Foucauldian approach, Ruiters emphasises the active agency of service recipients and the reciprocal dynamic of state power and popular mobilisation which mitigates against the simple realisation of state goals.

2. The research for the case study forms part of a broader research project on municipal approaches to reclaiming and recycling, commissioned by the environmental justice NGO groundWork. For a copy of the full report produced for groundWork, please see Samson (2008). The interviews were led by the author with assistance and translation provided by Moleleki Fantisi, Themba Mojikang and Zodwa Mtambo from the Vaal Environmental Justice Alliance (VEJA), and Musa Dlamini from groundWork. Many thanks to my colleagues for their invaluable assistance in conducting the research and for numerous insightful conversations regarding our analysis of the interviews. Thanks also to groundWork for permission to use the material. Although this paper draws on the research report produced for groundWork, the views expressed in this paper are my own and should not be attributed to VEJA or groundWork.

3. Many words are used to describe people who salvage re-useable and recyclable materials from the waste-stream. As will be discussed below, words such as 'scavenger' are seen as derogatory and rejected by the people who do this work. Although the commonly used term 'waste picker' is not necessarily derogatory, it does not capture the nature or importance of the labour being performed. The term 'recycler' is too narrow as not all goods salvaged are recycled. I prefer the term 'reclaimer' as it emphasises that, through their labour, people are reclaiming items cast aside by others, and are also reviving dead commodities and reclaiming the value inherent within them.

4. Personal communication with Assistant Manager, Health and Cleansing Services, Metsimaholo Municipality.

5. Ditamating means 'place of tomatoes' in seSotho. The committee picked this name as it is the nickname for Sasolburg due to the large number of tomatoes grown in the area. They said that choosing this name would help to ensure that the committee is seen as a local initiative.

6. Ikageng means 'build ourselves' in seSotho.

7. Their only history in the sector was one's role as a senior member in an initiative to promote recycling in the schools, a position he held due to his employment as a teacher in a primary school in Zamdela.

8. According to the Sasol Manager for Community and Government Relations, there were three main reasons why Sasol supported the project. Sasol believed that the project would help to protect the environment and would create 
employment. Importantly, Sasol had a vested interest in improving management of the dump as it owns the vacant land directly in front of the entrance to the dump. Previously, there had been problems with young reclaimers waiting on this land outside the gate and harassing community members who came to the dump. Many of these community members were employees who, according to the manager, complained about these activities. Sasol therefore wanted to intervene to bring order to recycling processes at the dump so as to protect its property as well as the interests of its employees (Interview, Zwane, 10/09/2008).

9. Letter from L. Thile, Manager Health and Cleansing, 22/05/2008.

10. The concept of the two economies has been subjected to wide and penetrating critique. See the articles in the special edition of Africanus (Bond 2007) for an overview of key arguments demonstrating the conceptual flaws in framing the formal and informal economies as distinct entities.

11. The example cited by Medina (undated:8) of how paramilitary groups in Colombia murdered 40 reclaimers, sold their organs for transplants and the rest of their bodies to the university to be dissected by medical students is perhaps the most shocking example of the expendability of reclaimers.

12. It should be noted that the member of the mayoral committee responsible for waste acknowledged that it was problem that council did not take the reclaimers seriously. When questioned as to whether it would be useful to have a landfill management committee (required by law for permitted sites) he said that this would be a good idea and he would work on it. He also raised concerns about the nature of the relationship between the officials and the reclaimers. However, in the nine months since he assumed his post, he had not been to the landfill and had not met with the reclaimers, about whom he knew very little. He was, nevertheless, a potential transformative force in the council.

\section{References}

ANC NGC, Jabu Moleketi, 2005, 'Discussion document: Development and Underdevelopment Learning from Experience to Overcome the Two-Economy Divide' in ANC National General Council.

Barchiesi, F., 2007, 'Privatization and the Historical Trajectory of "Social Movement Unionism”: A Case Study of Municipal Workers in Johannesburg', South Africa, International Labor and Working-Class History 71 (1):1-20.

Beall, J., 1997, 'Thoughts on Poverty from a South Asian Rubbish Dump: Gender, Inequality and Household Waste’, IDS Bulletin 28 (3):73-90.

Benjamin, S., 2007, Rapid Assessment on Scavenging and Waste Recycling Work by Children in South Africa, Pretoria: Programme Towards the Elimination of the Worst Forms of Child Labour (TECL), ILO. 
Bond, P. (ed), 2007, 'Special Issue, Transcending Two Economies: Renewed Debates in South African Political Economy', Africanus 37 (2).

Burchell, G., 1996, 'Liberal Government and Techniques of the Self'. In Foucault and Political Reason: Liberalism, Neo-liberalism and Rationalities of Government, edited by A. Barry, T. Osborne and N. Rose, Chicago: Chicago University Press.

Butler, J., 2004, Precarious Life: The Powers of Mourning and Violence, London: Verso.

Central Statistics, 1998, Women and Men in South Africa, Pretoria: Central Statistics.

Chari, S., 2005, 'Political Work: the Holy Spirit and the Labours of Activism in the Shadow of Durban's Refineries’, in From Local Processes to Global Forces. Centre for Civil Society Research Reports, Volume 1, Durban: University of KwaZulu-Natal (www.ukzn.ac.za/ccs/files/RReport_30.pdf , accessed August 15, 2008).

Chikarmane, P. and Narayan, L., 2005, Organising the Unorganised: A Case Study of the Kagad Kach Patra Kashtakari Panchayat (Trade Union of Wastepickers): www.wiego.org/program_areas/org_rep/case-kkpkp.pdf (last accessed March 7, 2008).

de Angelis, M., 2006, 'Enclosures, Commons and the “Outside”, In The Accumulation of Capital in Southern Africa Rosa Luxemburg's Contemporary Relevance. Proceedings of the Rosa Luxemburg Seminar 2006 and the University of KwaZulu-Natal, edited by P. Bond, H. Chitonge and A. Hopfmann, Johannesburg: Rosa Luxemburg Foundation.

Department of Environmental Affairs and Tourism and Department of Water Affairs, 1999, National Waste Management Strategy, Version D.

Dias, S.M., 2006, Waste and Citizenship Forums - Achievements and Limitations, paper \#11. In CWG-WASH Workshop, 2006, 1-5 February Kolkota, India.

Dias, S.M., 2007, An Assessment of Social Inclusion in SWM in Brazil Achievements and Challenges, Washington: Presentation to the World Bank, September 2007.

Goldsworthy, H., 2006, 'Book Review: Environmentality: Technologies of Government and the Making of Subjects', in The Journal of Environment Development 15:450-451.

Gordon, C., 1991, 'Governmental Rationality: an Introduction’. In The Foucault Effect: Studies in Governmentality, edited by G. Burchell, C. Gordon and P. Miller, Chicago: Chicago University Press.

Harden, I., 1992, The Contracting State. Buckingham: Open University Press.

Hart, G., 2006, 'Denaturalizing Dispossession: Critical Ethnography in the Age of Resurgent Imperialism', in Antipode 38 (5):977-1004.

Hart, G., 2008, The Provocations of Neoliberalism: Contesting the Nation and Liberation after Apartheid, in Antipode 40 (4):678-705.

Harvey, D., 2005, The New Imperialism, Oxford: Oxford University Press. 
Huysman, M., 1994, 'Waste Picking as a Survival Strategy for Women in Indian Cities', Environment and Urbanization 6 (2):155-174.

International Labour Organisation, 2004, Addressing the Exploitation of Children in Scavenging (Waste Picking): A Thematic Evaluation of Action on Child Labour, Geneva: International Programme on the Elimination of Child Labour (IPEC), ILO.

Kwezi V3 Engineers, 2008, IWMP for the Metsimaholo Municipality, (unpublished document).

Larner, W., 2000, 'Neoliberalism: Politics, Ideology, Governmentality', in Studies in Political Economy 63:5-25.

McDonald, D., 2002, 'The Theory and Practice of Cost Recovery in South Africa'. In Cost Recovery and the Crisis of Service Delivery in South Africa, edited by D. McDonald and J. Pape, Cape Town: HSRC.

Medina, M., 2007, The World's Scavengers: Salvaging for Sustainable Consumption and Production, Lanham, MD: Altamira Press.

Medina, M., undated, Waste Picker Cooperatives in Developing Countries.

Metsimaholo Municipality, 2008, Metsimaholo Sasolburg Integrated Development Plan, Review of the IDP 2007-2008, Sasolburg: Metsimaholo Municipality.

Millar, K., 2006, 'Recycling Class: Politics of the Informal Economy at a Brazilian Garbage Dump', MA Paper, Department of Anthropology, Brown University.

O’Malley, P., Weir, L. and Shearing, C., 1997, 'Governmentality, Criticism, Politics', in Economy and Society 26 (4):501-517.

Panitch, L., 1994, 'Globalisation and the State', in The Socialist Register: Between Globalism and Nationalism, edited by R. M. a. L. Panitch, London: Merlin Press.

Republic of South Africa, 2007a, National Environmental Management: Waste, Bill: Government Gazette No. 30142 of 3 August 2007.

Republic of South Africa, 2007b, Portfolio Committee Amendments to National Environmental Management: Waste Bill: Government Gazette.

Rogers, H., 2005, Gone Tomorrow: The Hidden Life of Garbage, New York: The New Press.

Rose, N., 1996, 'Governing in Advanced Liberal Democracies', in Foucault and Political Reason: Liberalism, Neo-liberalism and Rationalities of Government, edited by A. Barry, T. Osborne and N. Rose, Chicago: Chicago University Press.

Ruiters, G., 2007, 'Contradictions in Municipal Services in Contemporary South Africa: Disciplinary Commodification and Self-disconnections', in Critical Social Policy 27 (4):487-508.

Rutherford, S., 2007, 'Green Governmentality: Insights and Opportunities in the Study of Nature’s Rule, Progress in Human Geography 31 (3):291-307.

Samson, M., 2007, 'Privatizing Collective Public Goods - Re-fracturing the Public and Re-Segmenting Labour Markets: A Case Study of Street Cleaning in Johannesburg, South Africa', in Studies in Political Economy 79:119-143. 
Samson, M., 2008, Reclaiming Livelihoods: The Role of Reclaimers in Municipal Waste Management Systems, Pietermaritzburg: Groundwork.

Tejani, T., 2003, Scrap-collectors Fight For and Win a New Legitimacy April [cited].

Watts, M., 2003, 'Development and Governmentality’, in Singapore Journal of Tropical Geography 24 (1):6-34.

Webster, E., Benya, A., Dilata, X., Joynt, K., Ngoepe, K. and Tsoeu, M., 2007, Making Visible the Invisible: Confronting South Africa's Decent Work Deficit. Research Report prepared for the Department of Labour by the Sociology of Work Unit, University of the Witwatersrand, Johannesburg: SWOP.

Weszkalnys, G., 2007, 'Review: Environmentality: Technologies of Government and the Making of Subjects', in Environment and Planning D: Society and Space 25:376-377. 
